\title{
Histamine release from platelets for assay of byssinogenic substances in cotton mill dust and related materials
}

\author{
S. K. AINSWORTH, R. E. NEUMAN, AND R. A. HARLEY \\ From the Department of Pathology, Medical University of South Carolina, Charleston, South \\ Carolina, USA
}

\begin{abstract}
Previous reports suggest that byssinosis, an asthma-like condition among textile workers, may be mediated in part by histamine liberated following inhalation of dust. A simple, sensitive, and reliable procedure using pig platelets which contain the unusually high concentration of $0.8-1 \cdot 6 \mu \mathrm{g}$ histamine $/ 10^{9}$ cells has been devised for the assay of histamine-releasing factors in cotton mill dust and related materials, and has yielded results generally in accordance with earlier assays using chopped lung tissue. As little as 50-100 $\mu \mathrm{g}$ of total extractable substances from cotton mill dust can be measured. The activity of the extract is associated with the non-dialysable high molecular weight portion. However, conditions of acid hydrolysis do not destroy the activity. Extracts of leaves from different varieties of plant are highly potent, which suggests that the factors responsible for byssinosis are widely distributed plant components, present in textile fibre plants and converted to a respirable form by handling processes. Ellagic acid and sodium metasilicate release histamine from pig platelets, and represent new classes of compounds with possible roles in the aetiology of byssinosis.
\end{abstract}

Byssinosis affects as many as a quarter of the cotton workers in the United States, and is of increasing concern to the industry (Harris et al., 1972; Bouhuys, 1974). The primary symptoms are respiratory difficulty, tightness in the chest, shortness of breath, cough, and decreased forced expiratory ventilation. The effects are most severe after absence from work (on Monday or after holidays) but gradually diminish as the work week progresses. The incidence and harshness of the attacks are related to the atmospheric concentration of respirable dust particles from the cotton materials. The disease eventually can develop into a chronic form with accompanying disablement (Harris et al., 1972; Bouhuys, 1974).

Identification of the factor(s) in cotton mill dust which may be responsible for byssinosis could help to prevent or to alleviate this ailment. The nature of the symptoms and results of experimental studies suggest that induction of histamine release by cotton

Requests for reprints to S. K. Ainsworth, PhD, Department of Pathology, Medical University of South Carolina, Charleston, South Carolina 29403, USA.

Received for publication 15 March 1978

Accepted for publication 23 June 1978 dust may be involved in the aetiology of byssinosis as observed in asthma (Bouhuys and Lindell, 1961; Bouhuys, 1974). Antihistamines are reported to allay development of the symptoms of byssinosis in experimental studies (Bouhuys, 1963; Valić and Žuškin, 1973). Increased quantities of metabolites of histamine are excreted following exposure to textile dusts (Bouhuys et al., 1967; Edwards et al., 1970). Agents in cotton mill dust and cotton bract extracts induced release of histamine from chopped lung tissue (Bouhuys and Lindell, 1961; Nicholls et al., 1967; Evans and Nicholls, 1974b). On the basis of similar chemical properties these substances which release histamine apparently are identified as the bronchoconstricting agents of cotton dust in vivo (Douglas et al., 1974).

A major problem in the study of the byssinogenic agents has been the question of suitable assay systems. These have ranged from inhalation by human volunteers (Hamilton et al., 1973), leucocyte recruitment in the lungs of animals in vivo (Rylander and Nordstrand, 1974; Walker et al., 1975), and chemotaxis in Boyden chambers (Kilburn et al., 1977), to histamine release by chopped lung tissue (Bouhuys and Lindell, 1961; Evans and Nicholls, 
1974b). The latter method has been used in a number of productive studies. The rationale for the use of histamine release in vitro as an assay of byssinogenic agents can be based first, upon the evidence for the involvement of histamine in producing symptoms of byssinosis and second, on the repeated observation that extracts of cotton dust will induce histamine release in chopped lung tissue, as well as in the whole animal.

Unfortunately, in our laboratories and in others, the use of chopped lung tissues has appeared excessively laborious and not always reliable or sufficiently sensitive (Greenblatt, 1977). It occurred to us that leucocytes or, more precisely, basophils, might be employed satisfactorily in the detection of those substances in cotton dust that induce the liberation of histamine. While the mast cell is the localised source of histamine in the lung and other tissues, the blood-borne basophil in most species is the principal carrier of histamine in the circulation. Both mast cells and basophils contain histamine granules and respond to a number of the same agents that cause release of histamine (Cline, 1975). The specific release of histamine from sensitised basophils and tissue mast cells occurs in the presence of antigens (Mota, 1963; Lichtenstein and Osler, 1964).

In preliminary studies, pig leucocytes apparently did release histamine when treated with cotton mill dust extracts (Ainsworth and Neuman, 1977a). However, platelets which frequently persisted in leucocyte preparations were found to contribute significantly to histamine release, and to be superior as test cells. Although pig blood has a high histamine level (Lorentz et al., 1971), the exceptional histamine content of platelets $\left(0.8-1.6 \mu \mathrm{g} / 10^{9}\right.$ platelets or $80-90 \%$ of the blood histamine) has not been reported previously. The present report is concerned with the use of pig platelets to assay those agents in cotton mill dust or related material that may induce histamine release.

The use of histamine release from platelets for the detection and assay of possible byssinogenic agents, as in the chopped-lung assays, is based on the involvement of histamine as an effector mechanism in byssinosis, and on the fact that cotton mill dust extracts do release histamine from the platelets. Furthermore, results of the platelet assay method agree closely with published findings of choppedlung assay techniques.

\section{Material and methods}

Samples of cotton mill dust (electrostatically precipitated using a lint prefilter) were kindly supplied by the USDA Cotton Quality Research Station Model
Cardroom, Clemson University, Clemson, South Carolina. Gin trash was obtained from gins in Berkeley County, South Carolina, and cotton bracts and leaves were collected from cotton plants in the same area.

Extracts of cotton mill dust (CMDE), gin trash (GTE), cotton bracts and leaves were prepared by macerating in a mortar or shredding in a Waring Blender 5-15 g of material in $100 \mathrm{ml}$ of water. After the suspensions had stood for $12-16 \mathrm{~h}$ at $4{ }^{\circ} \mathrm{C}$, with occasional agitation, they were centrifuged at $2000 \mathrm{~g}$ for $30 \mathrm{~min}$ at $4^{\circ} \mathrm{C}$. The supernates were collected and stored at $-10^{\circ} \mathrm{C}$. Before use, the extracts were thawed and recentrifuged for $10 \mathrm{~min}$ to remove a brown precipitate that had formed. Dialysates of extracts were prepared by immersing extracts in cellulose dialysis tubing for $24 \mathrm{~h}$ in 2 volumes of water at $4^{\circ} \mathrm{C}$. Dialysed residues were prepared by dialysing (dialyser tubing from Fisher Scientific Co, Pittsburg, $\mathrm{Pa}$ ) the remaining contents of the tube against five changes of ten volumes of water at $4^{\circ} \mathrm{C}$ over $72 \mathrm{~h}$. Dry weights of extracts were determined by freezedrying aliquots of the supernate and weighing the product. For hydrolysis, samples were heated in $6 \mathrm{M} \mathrm{HCl}$ in sealed tubes at $105^{\circ} \mathrm{C}$ for $1-4 \mathrm{~h} . \mathrm{HCl}$ was removed by drying the solution at $100^{\circ} \mathrm{C}$ with a stream of air.

Pig blood was collected by needle puncture of the vena cava of an animal under restraint or, more usually, from the vena cava of pigs tranquillised by injection into the shoulder muscles of $10 \mathrm{mg}$ ketamine $\mathrm{HCl} / \mathrm{kg}$ body weight (Parke, Davis \& Co, Detroit, Michigan). Yorkshire pigs aged $18 \mathrm{wk}$ and weighing $50-60 \mathrm{~kg}$ were used. Platelets from blood obtained by either procedure showed the same histamine content and histamine-releasing activity.

Tris-buffered saline (TA) contained: tris (THAM; tr is(hydroxymethyl)aminomethane: Fisher Scientific Co, Pittsburgh, Pa), $25 \mathrm{mmol} / \mathrm{l} ; \mathrm{NaCl}, 120 \mathrm{mmol}$; $\mathrm{KCl}, 5 \mathrm{mmol} / 1$; and human serum albumin, (normal serum albumin (human) USP, $25 \%$ solution: Parke, Davis \& Co), $1 \mathrm{mg} / \mathrm{ml}$. TA with the further inclusion of $600 \mu \mathrm{mol} \mathrm{Ca} \mathrm{Ca}^{++} / 1$ and $1 \mathrm{mmol} \mathrm{Mg}^{++} / 1$ was designated TAC. The $\mathrm{pH}$ was adjusted with $\mathrm{HCl}$ to $\mathrm{pH} 7.65$ at $25^{\circ} \mathrm{C}\left(7.35\right.$ at $\left.37^{\circ} \mathrm{C}\right)$. Aqueous solutions of test samples were brought to the same basal composition of TAC by addition of concentrated stock solutions, and the $\mathrm{pH}$ was adjusted when necessary.

The procedure for determination of induced histamine release from platelets followed closely the method of Lichtenstein and Osler (1964) for determination of histamine release by sensitised human leucocytes in the presence of antigens. A major difference, of course, was the preparation of 
platelets rather than of leucocytes. One hundred $\mathrm{ml}$ of pig blood was collected in a plastic vessel containing $11.0 \mathrm{ml}$ of $0.1 \mathrm{M}$ EDTA (ethylenediamine tetra-acetic acid, disodium salt) $\mathrm{pH} 7 \cdot 7$, as an anticoagulant and preservative of the platelets. After sedimentation at $4^{\circ} \mathrm{C}$ for $1-2 \mathrm{~h}$, the platelet-rich plasma was drawn off and centrifuged at $100 \mathrm{~g}$ for $10 \mathrm{~min}$ to remove suspended red blood cells and leucocytes. The supernate was then centrifuged at $1200 \mathrm{~g}$ for $15 \mathrm{~min}$. The pellet of platelets was resuspended in cold $\left(4-10^{\circ} \mathrm{C}\right)$ TA. The cells were centrifuged and washed again. Finally the pellet was resuspended in $50-75 \mathrm{ml}$ TAC. This cell suspension usually contained $5-9 \times 10^{8}$ platelets $/ \mathrm{ml}$ and $0.4-0.8 \mu \mathrm{g}$ histamine $/ \mathrm{ml}$. Platelets were counted with the Coulter Counter (Model ZBI, Coulter Electronics, Inc, Hialeah, Florida). Test samples (in TAC) were distributed in $12 \times 75 \mathrm{~mm}$ tubes. The volume in every tube was made up to $1.0 \mathrm{ml}$ with TAC, and $0.5 \mathrm{ml}$ platelet suspension was added. Cell blanks were prepared with tubes containing TAC or sample solutions. The total histamine available from cells (designated 'cell completes') was determined from tubes containing cells and TAC which were treated directly with tricholoroacetic acid as described below, without previous removal of cells.

After the tubes had been incubated at $37^{\circ} \mathrm{C}$ for $30 \mathrm{~min}$ with occasional agitation, the reaction was stopped by placing the tubes in a water bath at $4^{\circ} \mathrm{C}$. The cell-free supernatant collected from centrifugation at $1200 \mathrm{~g}$ for $6 \mathrm{~min}$ was mixed with an equal volume of $10 \%$ trichloroacetic acid. After $30 \mathrm{~min}$ at room temperature the tubes were centrifuged at $1000 \mathrm{~g}$ for $10 \mathrm{~min}$. The clear supernatant was removed and its histamine content was determined by the fluorometric procedure of Shore et al. (1959). This procedure had been shown by Lorentz et al. (1971) to measure histamine accurately in all pig tissues tested, although whole blood extracts required additional treatment with Dowex 50 to eliminate interference that increased histamine results by $20 \%$. However, the washed platelets in the present work had been separated from whole blood, and histamine results were not altered by use of Dowex 50. The Hitachi Perkin Elmer Fluorescence Spectrophotometer No MPF-2A (Perkin Elmer Corp, Norwalk, Conn) was used to measure histamine concentration. Results were expressed in terms of relative fluorescent reading (RFR) or as per cent net histamine release.

All pipettes and containers used to handle and incubate cells were plastic or coated with Siliclad (Clay Adams, Parssippany, NJ) to minimise adhesion of the cells. Cells and all solutions used were maintained at $4{ }^{\circ} \mathrm{C}$ throughout the washing process and preparation of tubes for incubation.

\section{Results}

Extracts of cotton mill dust and related materials induced release of histamine from pig platelets prepared and incubated in the manner described. However, in order to ensure optimal conditions, these were varied individually and the results were observed. Gin trash extract, because of its high histamine-release activity and ready availability in unlimited quantities, was used in much of the laboratory work reported here. In all studies, extracts of cotton mill dust and gin trash, which might be considered to be its immediate precursor, gave the same results.

The effects of altering the $\mathrm{pH}$ of the incubation medium are shown in Table 1 and Figure 1. Small quantities of histamine escaped from the platelets over the entire $\mathrm{pH}$ range. A net histanine release was observed on exposure to extract with maximal response between pH $6 \cdot 8$ and $7 \cdot 4\left(7.7\right.$ at $\left.25^{\circ} \mathrm{C}\right)$. Substitution of phosphate buffer for TAC gave similar results. Each reported value is the mean of results from three incubation tubes, and the precision

Table 1 Effect of $p H$ on histamine release from pig platelets

\begin{tabular}{|c|c|c|c|c|}
\hline $\begin{array}{l}\text { pH of } \\
\text { incubator } \\
\text { medium* }\end{array}$ & $\begin{array}{l}G T \\
\text { extract } \\
(m l)\end{array}$ & $R F R \dagger$ & Net RFR & $\begin{array}{l}\text { Net release of } \\
\text { histamine } \S \\
(\%)\end{array}$ \\
\hline $6 \cdot 1$ & $\begin{array}{l}0 \cdot 0 \\
0 \cdot 2\end{array}$ & $\begin{aligned} 3 & \pm 0.0 \\
48 & \pm 1 \cdot 7\end{aligned}$ & $\overrightarrow{41}$ & $\overline{57}$ \\
\hline $6 \cdot 6$ & $\begin{array}{l}0 \cdot 0 \\
0 \cdot 2\end{array}$ & $\begin{array}{r}8 \pm 0.5 \\
54 \pm 0.7\end{array}$ & $\overline{42}$ & $\overline{58}$ \\
\hline $6 \cdot 8$ & $\begin{array}{l}0 \cdot 0 \\
0 \cdot 2\end{array}$ & $\begin{array}{r}7 \pm 1.5 \\
57 \pm 0.5\end{array}$ & $\overline{46}$ & $\overline{64}$ \\
\hline $7 \cdot 1$ & $\begin{array}{l}0 \cdot 0 \\
0 \cdot 2\end{array}$ & $\begin{array}{r}7 \pm 0 \cdot 0 \\
62 \pm 2 \cdot 0\end{array}$ & $\overline{51}$ & $\overline{71}$ \\
\hline $7 \cdot 4$ & $\begin{array}{l}0 \cdot 0 \\
0 \cdot 2\end{array}$ & $\begin{array}{r}7 \pm 1 \cdot 0 \\
58 \pm 1 \cdot 3\end{array}$ & $\overline{47}$ & $\overline{65}$ \\
\hline $7 \cdot 7$ & $\begin{array}{l}0 \cdot 0 \\
0 \cdot 2\end{array}$ & $\begin{array}{r}8 \pm 0 \cdot 5 \\
54 \pm 1 \cdot 0\end{array}$ & $\overline{42}$ & $\overline{58}$ \\
\hline $8 \cdot 0$ & $\begin{array}{l}0 \cdot 0 \\
0 \cdot 2\end{array}$ & $\begin{array}{r}8 \pm 1 \cdot 0 \\
48 \pm 2 \cdot 3\end{array}$ & $\overline{36}$ & $\overline{50}$ \\
\hline $8 \cdot 3$ & $\begin{array}{l}0 \cdot 0 \\
0 \cdot 2\end{array}$ & $\begin{array}{l}13 \pm 2 \cdot 0 \\
41 \pm 2 \cdot 3\end{array}$ & $\overline{24}$ & $\overline{33}$ \\
\hline \multicolumn{2}{|c|}{ Cell completes } & $72 \pm 3 \cdot 0$ & & \\
\hline
\end{tabular}

* 30 minutes' incubation at $37^{\circ} \mathrm{C}$; $\nmid R F R$ : relative fluorescent reading; $\ddagger$ Net RFR: RFR - (RFR of 0 tube + RFR of 4.0 for $0.2 \mathrm{ml} \mathrm{GT}$ extract); $\S$ Net release of histamine $=\frac{\text { net } \mathbf{R F R}}{\text { RFR of cell completes }} \times 100 \%$ TValues represent the mean of 3 tubes, and the average deviation of each tube from the mean. 


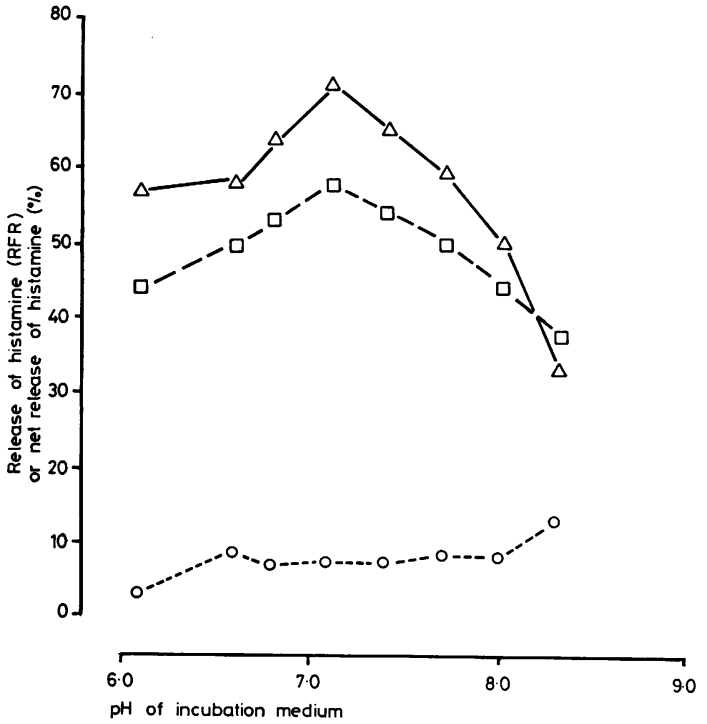

Fig. 1 The effect of $\mathrm{pH}$ of incubation medium on release of histamine. Circles, $0 \mathrm{ml}$ gin trash extract, RFR. Squares, $0 \cdot 2 \mathrm{ml}$ gin trash extract, RFR. Triangles, net histamine release, \%. Incubation for $30 \mathrm{~min}$ at $37^{\circ} \mathrm{C}$.

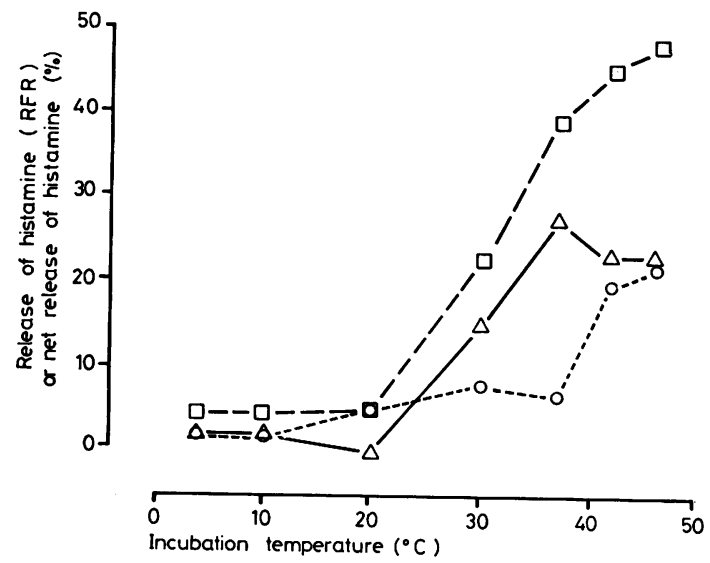

Fig. 2 Release of histamine at different incubation temperatures. Symbols as in Fig. 1. Incubation for 30 minutes.

of the experiment is expressed as the average deviation of the result from each tube, from the mean.

Figure 2 shows the effect of variation in temperature of incubation. The spontaneous release of histamine remained low at $4-37^{\circ} \mathrm{C}$, and increased thereafter. Below $20^{\circ} \mathrm{C}$ the extract did not stimulate a significant release. With a further increase in temperature, the extract elicited histamine release with a maximal net effect at $37^{\circ} \mathrm{C}$. Higher histamine values were obtained at $42-46^{\circ} \mathrm{C}$, but this was attributable to greater losses from untreated cells, and did not, therefore, indicate a net increase in histamine release.

Figure 3 shows histamine release throughout the incubation period. Untreated pig platelets lost small amounts of histamine which gradually increased over a period of $60 \mathrm{~min}$. Histamine values from test platelets, after an initial lag, rose after $20-30 \mathrm{~min}$ to a maximum which remained fairly constant. Net histamine release was maximal at $30 \mathrm{~min}$.

The results obtained with different concentrations of platelets in the histamine release assay are shown in Figure 4. Histamine found in the medium of untreated as well as treated cells, increased in proportion to the concentration of platelets. However, at each platelet concentration the net percentage histamine release, calculated from the ratio of histamine in the medium to the total available from the platelets (cell completes), was approximately the same at the different platelet concentrations.

Recovery of histamine added to the test systems is shown in Table 2. The low recovery of histamine from the TAC medium alone was consistent with $30 \%$ losses during extraction with organic solvents during the fluorimetric histamine determination. However, no further losses occurred upon incubation with extracts and platelets so that, essentially, complete recovery was achieved.

Table 3 compares the histamine released from platelets prepared from two different pigs in two different experiments. Graded quantities of identical samples of cotton mill dust and a dialysed freezedried gin trash extract were assayed. As little as $0.04 \mathrm{mg}$ of the cotton mill dust extract and 0.09 $\mathrm{mg}$ of the freeze-dried extract per $\mathrm{ml}$ in terms of extracted material were detectable. Net histamine released up to values near $50 \%$ was proportional to the amount of test substances. Therefore, the amount of test materials required for $25 \%$ net histamine release, equivalent to approximately half the maximal release of histamine, was often used to compare the potency of samples. Duplicate assays of samples compared in this manner gave acceptably similar results.

Application of the pig platelet assay to a variety of samples gave the results shown in Table 4. The data in Tables 2 and 3 bear witness to the reliability of these values. The assays gave results which did not vary over more than a $10 \%$ range of the net histamine release. Extracts of cotton mill dust, gin trash, cotton bracts, and leaves all gave a maximal net histamine release of $31-74 \%$. This effect was achieved by $0.7-3.3 \mathrm{mg}$ of dry weight of extract $/ \mathrm{ml}$. Net release of $25 \%$ histamine required only 0.2 $1.7 \mathrm{mg} / \mathrm{ml}$. These quantities of extracts generally 


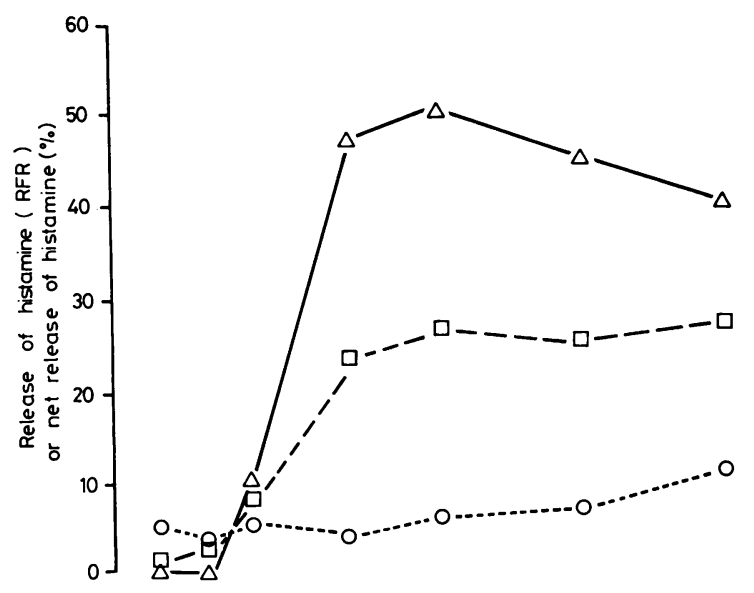

Fig. 3 Release of histamine from platelets during the course of incubation. Symbols as in Fig. 1. Incubation at $37^{\circ} \mathrm{C}$.

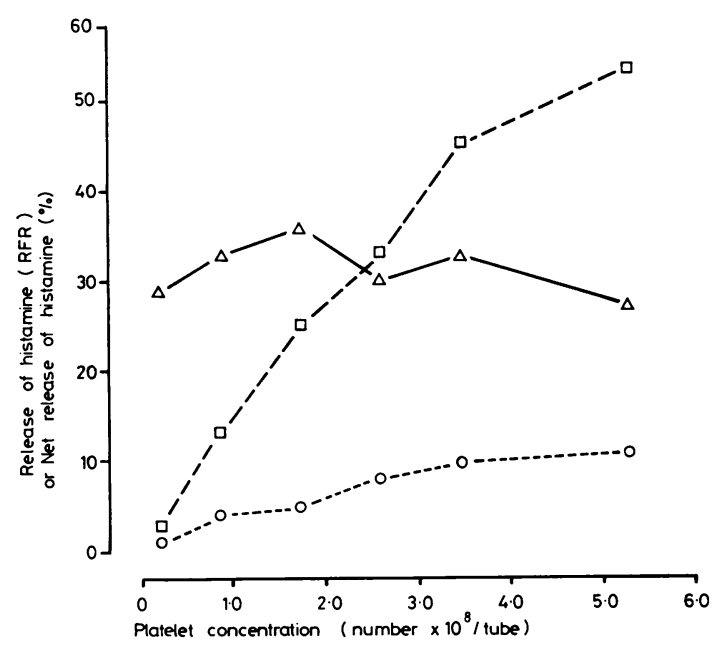

Fig. 4 Relationship of concentration of platelets to release of histamine. Symbols as in Fig. 1. Incubation for 30 minutes at $37^{\circ} \mathrm{C}$.

represented $10-20 \%$ of the dry weight of the original samples.

The data in Table 4 show that extracts of leaves from other plant sources, the pecan and grape, are similar to the cotton extracts in their effects. Byssinosan prepared from gin trash following the procedure of Mohammed et al. (1971) and 'polyphenols' prepared from gin trash following the procedure of Taylor et al. (1971) were relatively inactive.
Concentrations up to $10 \mathrm{mg} / \mathrm{ml}$ of human serum albumin, yeast RNA, adenosine triphosphate, lysozyme, dextran, methyl cellulose, glycine, alanine, histidine, arginine, glutamic acid and aspartic acid were inactive. Activities of dialysed residues of CMDE and GTE preparations were comparable to those of the original extracts, and the activity persisted after acid hydrolysis. Dialysates of CMDE and GTE were relatively inactive. Rutin and trimethylamine released histamine from pig platelets. Among tannin substances tested, quercetin and catechin (flavonoids of the condensed tannin group) and tannic acid (a hydrolysable gallotannin) showed low activity. However, ellagic acid, derived from a remaining group of hydrolysable tannins, the ellagitannins, did release histamine. Sodium metasilicate was found to have a similar high degree of effectiveness.

\section{Discussion}

The studies described here suggest that the conditions originally developed by Lichtenstein and Osler (1964) for the assay of histamine release with sensitised human leucocytes, also fall into the optimal range for the present assay of histamine release substances with pig platelets. Antweiler (1960) originally used animal blood to assess the histamine-releasing activity of cotton dust. Pig blood was used in the present studies because pig lung was known to be sensitive to cotton dust extracts and investigation showed that pig platelets had a 
Table 2 Recovery of histamine added to platelets and test media

\begin{tabular}{|c|c|c|c|c|c|}
\hline \multirow[t]{2}{*}{ Contents of incubation tube* } & \multirow[t]{2}{*}{ Number of tubes } & \multirow[t]{2}{*}{$R F R$} & \multicolumn{3}{|l|}{ Histamine } \\
\hline & & & $\begin{array}{l}\text { Found } \\
(\mu g / \text { tube })\end{array}$ & Released & Recovered \\
\hline $\begin{array}{l}\text { Without platelets } \\
\text { Medium } \\
\begin{aligned} \text { Medium } & +0.2 \mu \mathrm{g} \text { histamine } \\
\text { Medium } & +0.2 \mathrm{ml} \text { GTE } \\
\text { Medium } & +0.2 \mu \mathrm{g} \text { histamine } \\
& +0.2 \mathrm{ml} \text { GTE }\end{aligned}\end{array}$ & $\begin{array}{l}2 \\
3 \\
2 \\
3\end{array}$ & $\begin{aligned} 0.0 & \pm 0.0 \dagger \\
59 \cdot 5 & \pm 0 \cdot 5 \\
5 \cdot 7 & \pm 0 \cdot 4 \\
67 \cdot 7 & \pm 0 \cdot 1\end{aligned}$ & $\begin{array}{l}0.000 \\
0.141 \\
0.015 \\
0 \cdot 156\end{array}$ & $\begin{array}{l}\overline{-} \\
\overline{-}\end{array}$ & $\begin{array}{l}\overline{0 \cdot 141} \\
\overline{0 \cdot 141}\end{array}$ \\
\hline $\begin{array}{l}\text { With platelets } \\
\text { Medium } \\
\begin{aligned} & \text { Medium }+0.2 \mu \mathrm{g} \text { histamine } \\
& \text { Medium }+0.2 \mathrm{ml} \text { GTE } \\
& \text { Medium }+0.2 \mu \mathrm{g} \text { histamine } \\
&+0.2 \mathrm{ml} \mathrm{GTE}\end{aligned}\end{array}$ & $\begin{array}{l}2 \\
3 \\
2 \\
3\end{array}$ & $\begin{array}{r}27 \cdot 0 \pm 1 \cdot 0 \\
87 \cdot 3 \pm 4 \cdot 7 \\
82 \cdot 5 \pm 2 \cdot 5 \\
144 \cdot 0 \pm 3 \cdot 9\end{array}$ & $\begin{array}{l}0 \cdot 064 \\
0 \cdot 207 \\
0 \cdot 195 \\
0 \cdot 341\end{array}$ & $\begin{array}{l}- \\
\overline{0} \cdot 116 \\
(0 \cdot 116)\end{array}$ & $\begin{array}{l}\overline{0} \cdot 143 \\
\overline{0} \cdot 146\end{array}$ \\
\hline
\end{tabular}

* 30 minutes' incubation at $37^{\circ} \mathrm{C}$; $\uparrow$ Values represent the mean of 3 tubes, and the average deviation of each tube from the mean; 'Histamine found' represents value corrected for aliquots, but not for losses in extraction.

high histamine content and response.

This assay procedure provides a relatively homogeneous cell population that may be dispensed easily and reproducibly in replicate tubes by simple pipetting. The method is sensitive enough to enable $50 \%$ of the available histamine to be released by $3 \mathrm{mg}$ of cotton mill dust, or by submilligram quantities of extract. In contrast, $100-200 \mathrm{mg}$ of cotton mill dust has been necessary to release $5-15 \%$ of histamine from chopped pig lung. These differences are possibly attributable in part to mechanical barriers to diffusion in lung fragments. In both the platelet and the chopped lung assays, rutin and trimethylamine, found in cotton mill dust, and a high molecular weight fraction of cotton dust extracts (Evans and Nicholls, 1974a) induced histamine release. Previous studies (Ainsworth and

Table 3 Platelet histamine release from different pigs

\begin{tabular}{|c|c|c|c|c|}
\hline \multirow{2}{*}{$\begin{array}{l}\text { Equivalent } \\
\text { of original } \\
\text { sample } \\
(\mathrm{mg} / \mathrm{ml})\end{array}$} & \multirow{2}{*}{$\begin{array}{l}\text { Soluble } \\
\text { extract } \\
(\mathrm{mg} / \mathrm{ml})\end{array}$} & \multicolumn{2}{|c|}{$\begin{array}{l}\text { Net histamine release } \\
(\%)\end{array}$} & \multirow{2}{*}{$\begin{array}{l}\text { Requirement } \\
\text { for } 25 \% \text { net } \\
\text { release } \\
(\mathrm{mg} / \mathrm{ml})\end{array}$} \\
\hline & & Pig no. 54 & Pig no. 55 & \\
\hline \multicolumn{5}{|c|}{ Cotton mill dust extract no. 9B } \\
\hline 0 & 0 & 0 & 0 & \\
\hline 0.07 & 0.022 & 6 & & \\
\hline $\begin{array}{l}0.17 \\
0.33\end{array}$ & $\begin{array}{l}0.037 \\
0.067\end{array}$ & $\begin{aligned} & 1 \pm 0.02 \dagger \\
& 10 \pm 0.05\end{aligned}$ & $\begin{array}{l}4 \pm 0.6 \\
9\end{array}$ & \\
\hline $\begin{array}{l}0.33 \\
0.66\end{array}$ & $\begin{array}{l}0.067 \\
0.15\end{array}$ & $\begin{array}{l}10 \pm 0.05 \\
20\end{array}$ & $\frac{9}{20} \pm 1.4$ & \\
\hline $1 \cdot 65$ & $0 \cdot 37$ & $35 \pm 0.4$ & $46 \pm 1 \cdot 5$ & \\
\hline $3 \cdot 3$ & $0 \cdot 72$ & $60 \pm 3 \cdot 8$ & $59 \pm 0.9$ & $(0.21 \pm 0.01)$ \\
\hline
\end{tabular}

Dialysed freeze-dried gin trash extract

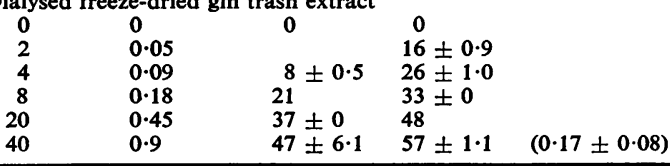

A platelet suspension was prepared from each pig. The same samples of CMD and GT extracts were assayed using different platelet suspensions, and a 30 -minute incubation at $37^{\circ} \mathrm{C}$.

†Values represent the mean of 3 tubes, and the average deviation of each tube from the mean.
Neuman, 1977a, b) showed that histamine-release activity was associated with high molecular weight fractions prepared from extracts by chromatography on Sephadex G-100, by ultrafiltration or by dialysis. However, despite acid lability of the factor determined by chopped lung assay, acid hydrolysates of the dialysed residues continued to cause histamine release from platelets.

Tannins are still under investigation in this laboratory as possible byssinogenic agents. Not only did several tannin compounds induce histamine release from chopped lung as well as from pig platelets, but they have chemical properties that may apply to the suspected histamine release factor(s) of cotton mill dust. Tannins might be expected to associate with other plant constituents, to form higher molecular weight polymers themselves, and to contain components that survive acid hydrolytic conditions (Haslam, 1966). Furthermore, as a prototype, a eucalyptus tannin fraction is extremely hypotensive in rats and apparently was the first tannin reported to have histamine-liberating activity (Read et al., 1970). Moreover, ellagic acid was reported to release kinins and to lower blood pressure in the rat (Gautivik and Rugstad, 1967). The tannins are components of cotton mill dust and related materials, and are also widely distributed in the plant kingdom (Haslam, 1966; Taylor et al., 1971). Byssinosis occurs in textile industries which use plant materials of diverse origin such as cotton, flax (Bouhuys et al., 1961), hemp (Bouhuys et al., 1967), and sisal (Nicholls et al., 1973). These are subjected to the action of high-speed machinery, likely to produce particles of respirable dimensions which contain a common component of plants, such as tannins. Where wool or silk is the raw material, byssinosis is unknown. Presumably, wherever inhalation of suitably sized dust of plant materials 
Table 4 Histamine release induced by cotton mill dust extract and related materials in pig platelet assay

\begin{tabular}{|c|c|c|c|}
\hline \multirow[t]{2}{*}{ Preparation or substance } & \multirow{2}{*}{$\begin{array}{l}\text { Maximum net histamine } \\
(\%)\end{array}$} & \multicolumn{2}{|c|}{ Quantity of test material $*$ required for: } \\
\hline & & $\begin{array}{l}\text { Maximum net release } \\
(\mathrm{mg} / \mathrm{ml})\end{array}$ & $\begin{array}{l}25 \% \text { net release } \\
(\mathrm{mg} / \mathrm{ml})\end{array}$ \\
\hline $\begin{array}{l}\text { Cotton mill dust extract (CMDE) } \\
\text { Gin trash extract (GTE) } \\
\text { Cotton bract extract } \\
\text { Cotton leaf extract } \\
\text { Pecan leaf extract } \\
\text { Grape leaf extract } \\
\text { Dialysed CMDE } \\
\text { Dialysed GTE } \\
\text { Byssinosan } \\
\text { Polyphenols } \\
\text { Acid hydrolysate of CMDE } \\
\text { Acid hydrolysate of } \mathrm{GTE} \\
\text { Compound } 48 / 80 \dagger \\
\text { Rutin } \\
\text { Trimethylamine } \mathrm{HCl} \ddagger \\
\text { Quercetin } \ddagger \\
\text { Catechin } \ddagger \\
\text { Tannic acid } \S \\
\text { Ellagic acid } \ddagger \\
\text { Sodium metasilicate } \S\left(\mathrm{Na}_{2} \mathrm{SiO}_{3} 9 \mathrm{H}_{2} \mathrm{O}\right)\end{array}$ & $\begin{array}{r}50 \\
74 \\
31 \\
43 \\
67 \\
58 \\
49 \\
57 \\
6 \\
3 \\
62 \\
41 \\
40 \\
46 \\
43 \\
4 \\
6 \\
6 \\
17 \\
43 \\
64\end{array}$ & $\begin{array}{l}0 \cdot 72 \\
3 \cdot 3 \\
1 \cdot 0 \\
2 \cdot 8 \\
0 \cdot 4 \\
1 \cdot 5 \\
1 \cdot 2 \\
0 \cdot 9 \\
3 \cdot 0 \\
7 \cdot 0 \\
1 \cdot 7 \\
0 \cdot 9 \\
1 \cdot 0 \\
1 \cdot 0 \\
1 \cdot 0 \\
1 \cdot 0 \\
0 \cdot 6 \\
1 \cdot 0 \\
0 \cdot 6 \\
0 \cdot 28\end{array}$ & $\begin{array}{l}0 \cdot 21 \\
0 \cdot 30 \\
0 \cdot 7 \\
1 \cdot 7 \\
0 \cdot 044 \\
0 \cdot 11 \\
0 \cdot 20 \\
0 \cdot 17 \\
- \\
- \\
0 \cdot 54 \\
0 \cdot 31 \\
0 \cdot 20 \\
0 \cdot 18 \\
0 \cdot 17 \\
- \\
- \\
\overline{0.16} \\
0.024\end{array}$ \\
\hline
\end{tabular}

*Extracts in terms of freeze-dried weights; †Burroughs Wellcome Co; ¥Sigma Chemical Co, St. Louis, Mo; §Fisher Scientific Co.

containing histamine-releasing substances occurs, acute byssinotic symptoms are likely. However, physical irritation by particles and further biochemical effects could contribute to the production of symptoms, especially to the irreversible pathology of the chronic byssinotic syndrome.

Silicate is a second type of widely distributed substance that induces release of histamine from platelets. Silicon is a common constituent of plant tissues in the form of dissolved hydrous silica or silicic acids (Bailar et al., 1973), which may contribute to the byssinotic syndrome. Silica has been reported to release histamine from lung in vitro (Religa and Malinski, 1970). Cotton bracts contain 0.4-0.8\% silicon (Wakelyn et al., 1977).

In the present study, the pig platelet assay of histamine-releasing substances is presented as a tool and not necessarily as a model system. It is not known at present whether platelets are directly involved in byssinosis. However, a reduction of platelets of cotton mill workers on the first day of the work week was reported by Bomski et al. (1971). An abundance of prostaglandins, serotonin and a quantity of histamine is present even in human platelets (Clausen and Srivastava, 1972; Seidel et al., 1973). These compounds are bronchoconstricting substances, and prostaglandins and serotonin are taken up avidly by lung tissue (Adkinson, 1977). Furthermore, almost the entire platelet population of the blood traverses the lungs every few minutes. In certain asthma-like conditions (as in anaphylaxis of the guinea pig) bronchospasm and circulatory shock are mediated by histamine from platelets trapped in the lung (Aviado, 1976). Trauma in the dog leads to the accumulation of large numbers of platelets in the lungs, but not in other organs tested (Ljungqvist et al., 1971). A special affinity of the lungs for platelets, rather than filter properties alone, was proposed as an explanation (Bergentz et al., 1972). This hypothesis is not unreasonable despite the simpler interpretation that the histamine release from the platelets is an instance of the well-known release reaction of platelets in response to such substances as adenosine diphosphate, thrombin or collagen (Caens et al., 1977).

This work was supported by funds from Cotton, Incorporated.

\section{References}

Adkinson, N. F., Jr. (1977). Role of biochemicals endogenous to the lung. In Muscular Exercise and the Lung, pp. 211224. Edited by J. A. Dempsey and C. E. Read, University of Wisconsin Press: Madison, Wisconsin.

Ainsworth, S. K., and Neuman, R. E. (1977a). Biological activity of cotton dust and cotton plant extracts detected by chemotaxis and leucocyte histamine release assay. In Proceedings, 1977 Beltwide Cotton Production Research Conference, Atlanta, Georgia, pp. 76-78. Edited by P. J. Wakelyn and P. E. Sasser. National Cotton Council of America: Memphis, Tennessee.

Ainsworth, S. K., and Neuman, R. E. (1977b). Some chemical properties of cotton plant dust and cotton extracts. In Proceedings, 1977 Beltwide Cotton Production Research Conference, Atlanta, Georgia, pp. 62-63. Edited by P. J. Wakelyn and P. E. Sasser. National Cotton Council of America: Memphis, Tennessee.

Antweiler, H. (1960). Observations upon a histamine liberat- 
ing substance in cotton dust. Annals of Occupational Hygiene, 2, 152-156.

Aviado, M. (1976). Biogenic amines, cigarette smoke and pulmonary emphysema. In Air Pollution and the Lung, p. 107. Edited by E. F. Aharonson, A. Ben-David, and M. A. Klingberg. John Wiley \& Sons: New York.

Bailar, J. C., Emelius, H. J., Nyholm, R., and TrotmanDickenson, A. F. (1973). In Comprehensive Inorganic Chemistry, p. 1344. Pergamon Publishers: New York.

Bergentz, W. E., Ljungqvist, U., and Lewis, D. H. (1972). The distribution of platelets, fibrin and erythrocytes in various organs following thrombin infusion: an experimental study in dogs with and without antifibrinolytic therapy. Surgery, 71, 190-195.

Bomski, H., Otawski, J., and Bomska, H. (1971). Hematologische und Serologische Untersuchungen bei Byssinosegefahrdeten Arbeitern. Internationales Archiv für Arbeitsmedizin, 27, 309-323.

Bouhuys, A. (1963). Prevention of Monday dyspnoea in byssinosis: a controlled trial with an antihistamine drug. Clinical Pharmacology and Therapeutics, 4, 311-314.

Bouhuys, A. (1974). In Breathing, pp. 416-440. Grune and Stratton: New York.

Bouhuys, A., and Lindell, S. E. (1961). Release of histamine by cotton dust extracts from human lung tissue in vitro. Experientia, 17, 211-212.

Bouhuys, A., Van Duyn, J., and Van Lenney, J. J. (1961). Byssinosis in flax workers. Archives of Environmental Health, 3, 499-509.

Bouhuys, A., Barbero, A., Lindell, S. E., Roach, S. A., and Schilling, R. S. F. (1967). Byssinosis in hemp workers. Archives of Environmental Health, 14, 533-544.

Caens, J. P., Cronberg, S., and Kubisz, O. (1977). In Platelets, Physiology and Pathology, pp. 28-29. Stratton Intercontinental Medical Book Corporation: New York.

Clausen, J., and Srivastava, K. C. (1972). The synthesis of prostaglandins in human platelets. Lipids, 7, 247-250.

Cline, M. J. (1975). In The White Cell, pp. 129-130. Harvard University Press: Cambridge, Massachusetts.

Douglas, J. S., Žuškin, E., and Bouhuys, A. (1974). Relationship between in vivo bronchospasm induced by textile dust extracts and in vivo histamine release from pig lung. American Journal of Respiratory Disease, 109, 712-713.

Edwards, J., McCarthy, P., McDermott, M., Nicholls, P. J., and Skidmore, J. E. (1970). The acute physiological, pharmacological and immunological effects of inhaled cotton dust in normal subjects. Journal of Physiology, 208, 63.

Evans, E., and Nicholls, P. J. (1974a). Preliminary characterization of the histamine releasing activity of cotton dust. Journal of Pharmacy and Pharmacology, 26S,115.

Evans, E., and Nicholls, P. J. (1974b). Studies on the mechanism of histamine release from lung tissue in vitro by cotton dust extracts. Agents and Actions, 5, 304-310.

Gautivik, K. M., and Rugstad, H. E. (1967). Kinin formation and kininogen depletion in rats after intravenous injection of ellagic acid. British Journal of Pharmacology and Chemotherapy, 31, 390-400.

Greenblatt, G. A. (1977). Histamine release from excised pig lung tissue induced by cotton bracts. In Proceedings, 1977 Beltwide Cotton Production Research Conference, Atlanta, Georgia, pp. 71-72. Edited by P. J. Wakelyn and P. E. Sasser. National Cotton Council of America: Memphis, Tennessee.

Hamilton, J. D., Halprin, G. M., Kilburn, K. H., Merchant, J. A., and Ujda, J. R. (1973). Differential aerosol challenge studies in byssinosis. Archives of Environmental Health, 26, 120-124.

Harris, T. R., Merchant, J. A., Kilburn, K. H., and Hamilton, J. D. (1972). Byssinosis and respiratory disease of cotton mill workers. Journal of Occupational Medicine, 14, 199-206.

Haslam, E. (1966). In Chemistry of the Vegetable Tannins, pp. 8-12. Academic Press: New York.

Kilburn, K. H., McCormick, J. P., Schafer, T. R., Thurston, R. J., and McKenzie, W. N. (1977). Biologically active components in cotton dust. In Proceedings, 1977 Beltwide Cotton Production Research Conference, Atlanta, Georgia, p. 66. National Cotton Council of America: Memphis, Tennessee.

Lichtenstein, L. M., and Osler, A. G. (1964). Studies on the mechanisms of hypersensitivity phenomena. IX. Histamine release from human leukocytes by ragweed pollen antigen. Journal of Experimental Medicine, 120, 507-530.

Ljungqvist, U., Bergentz, S. E., and Lewis, D. H. (1971). The distribution of platelets, fibrin and erythrocytes in various organs following experimental trauma. European Surgical Research, 3, 293-305.

Lorentz, W., Barth, H., Kusche, J., Reimann, H. J., Schmal, A., Matejka, E., Mathias, Ch., Hutzel, M., and Werle, E. (1971). Histamine in the pig: determination, distribution, release, and pharmacological actions. European Journal of Pharmacology, 14, 155-174.

Mohammed, Y. S., El-Gazzar, R. M., and Adamyova, K. (1971). Byssinosan, an aminopolysaccharide isolated from cotton dust. Carbohydrate Research, 20, 431-435.

Mota, I. (1963). Mast cells and anaphylaxis. Annals of the New York Academy of Sciences, 103, 264-277.

Nicholls, P. J., Evans, E., Valić, F., and Žuškin, E. (1973). Histamine releasing activity and bronchoconstricting effects of sisal. British Journal of Industrial Medicine, 30, 142-145

Nicholls, P. J., Nicholls, G. R., and Bouhuys, A. (1967). Histamine release by Compound $48 / 80$ and textile dusts from lung tissue in vitro. In Inhaled Particles and Vapours II. pp. 69-74. Edited by C. N. Davies. Pergamon Press: Oxford.

Read, G. W., Naguwa, G. S., Wigington, J. J., and Lenney, J. F. (1970). A histamine liberator in the tannin fraction of the eucalyptus. Lloydia, 33, 461-471.

Religa, Z., and Malinski, C. (1970). Histamine metabolism in experimental silicosis. I. Experiments on the isolated rat lung and on guinea pig lung homogenates and sections. Life Sciences, 9, 689-700.

Rylander, R., and Nordstrand, A. (1974). Pulmonary cell reactions after acute exposure to cotton dust extract. British Journal of Industrial Medicine, 31, 220-223.

Seidel, G., Engels, H. W., and Meyer-Burgdorff, C. (1973). Serotonin and histamine in platelets in the course of operation with extracorporeal circulation. Agents and Actions, 3, 168-171.

Shore, P. A., Burkhalter, A., and Cohn, V. H. (1959). A method for the fluorometric assay of histamine in tissues. Journal of Pharmacology and Experimental Therapeutics, 127, 182-186.

Taylor, G., Massoud, A. A. E., and Lucas, F. (1971). Studies on the aetiology of byssinosis. British Journal of Industrial Medicine, 28, 143-151.

Valić, F., and Žuškin, E. (1973). Pharmacological prevention of acute ventilatory capacity reduction in flax dust exposure, British Journal of Industrial Medicine, 39, 381-384.

Wakelyn, P. J., Brown, D. F., and Greenblatt, G. A. (1977). Chemical composition of cotton bracts. In Proceedings, 1977 Beltwide Cotton Production Research Conference, Atlanta, Georgia, pp. 52-54. Edited by P. J. Wakelyn and P. E. Sasser. National Cotton Council of America: Memphis, Tennessee.

Walker, R. F., Eidson, G., and Hatcher, J. D. (1975) Influence of cotton dust inhalation on free lung cells in rats and guinea pigs. Laboratory Investigation, 33, 28-32. 